\title{
CEDEC 30 ANOS
}

\section{Paulo Eduardo Elias}

Trinta anos não são poucos para instituições como o Cedec. Fundado nos anos da ditadura, aglutinou intelectuais com impedimentos de exercício pleno nas universidades públicas e privadas. Privilegiando a questão da democracia e enfatizando o papel dos movimentos sociais, o Cedec não perdeu de vista os temas relacionados à cultura, especialmente os aspectos da política. Contando com o apoio de instituições estrangeiras de fomento, entre as quais se destaca a Fundação Ford, e como convinha à época, logo aglutina seus quadros em torno de uma revista - Lua Nova - que virá a se constituir em símbolo e âncora intelectual do Cedec. O Editorial de seu primeiro exemplar ilustra magnificamente o ideário dos fundadores, ao afirmar a necessidade de uma reflexão sobre a ação política, social e econômica da atualidade em uma revista capaz de afrontar a realidade a partir de uma reflexão plural, apoiada na diversidade de pontos de vista que formam a sociedade.

Os tempos da abertura democrática e a retomada das liberdades de organização com a (re)fundação dos partidos políticos realimentam necessidades e compromissos do 
Cedec e da Lua Nova. Agora são tempos da ação política nos partidos, apoiada na reflexão cada vez mais teórica presente nas páginas da nossa revista. Há também a retomada da plena liberdade intelectual nos meios universitários. Naquela época, órgãos de fomento nacional, tais como a Financiadora de Estudos e Projetos (Finep) se aliam aos internacionais agora reforçados pela Novib, no estímulo à expressão do pensamento crítico além das universidades o que dá sobrevida aos projetos da instituição. Como afirmou Marilena Chauí em um dos Seminários em comemoração desta data, é inegável a importância do Cedec no cenário intelectual e político nos últimos trinta anos como pode atestar o seu grande acervo intelectual de pesquisas e publicações.

Contudo, a década final do Século XX, com a revolução nas comunicações advinda principalmente da informática e o êxito das políticas públicas conduzidas por agências de fomento federais e estaduais para a indução de padrões de produção de conhecimento sob o parâmetro das ciências "duras", repercute intensamente nos meios universitários e fora deles, nas instituições congêneres ao Cedec. Assim, ao lado da sempre presente necessidade da busca por financiamento, agora também encontramo-nos às voltas com novos desafios, tais como o de repensar formas e modos de realizar e divulgar nosso trabalho intelectual sem, no entanto, descuidar do ideário fundador, isto é, a reflexão crítica e plural do ponto de vista político.

Este nos parece ser o legado e ao mesmo tempo o desafio neste início de Século, mas agora com o agravo de condições muito adversas nacional e internacionalmente para o financiamento de entidades de pesquisa não universitárias que se pretendam minimamente autônomas, especialmente em relação a governos e partidos, e críticas do ponto de vista da produção de conhecimentos.

Sabedores de situações similares de instituições congêneres, algumas delas infelizmente já inviabilizadas, mais per- 
guntas que respostas temos a oferecer neste novo momento de inflexão do Cedec.

Sem esmorecer e contando com a solidariedade e apoio do Conselho Deliberativo, dos associados e dos funcionários, buscamos novos horizontes e meios para enfrentarmos os desafios do financiamento, mas também, e principalmente, o da produção intelectual e sua divulgação. É de nossa obrigação assim proceder sem, contudo, perder de vista o legado dos fundadores, traduzido no compromisso com a democracia como expressão da res publica e da cidadania como direito social.

Lutamos e cremos na necessidade de espaço para a produção crítica e contemporânea para além da universidade - até por sua visível crise intelectual e de gestão na atualidade -, mas só o tempo dirá sobre o sucesso desta empreitada.

Na sua idade da razão, resta-nos proclamar ao Cedec: ARS LONGA.

\section{Paulo Eduardo Elias}

é professor do Departamento de Medicina Preventiva da Faculdade de Medicina da USP e presidente do Cedec 